\title{
Investigation of Self-Efficacy Levels of Football Referees
}

\author{
Çağatay DERECELİ $\quad$ Hüseyin ÜNLÜ** \\ Mustafa Kaylhan ERBAŞ ${ }^{* * *}$
}

\begin{abstract}
In this study, we aimed to examine the self-efficacy levels of soccer referees in the context of some demographic variables (gender, education level, age of starting refereeing, and ocupation). The study group consisted of a total of 154 soccer referees during the 2017-2018 football season of whom 33 (21.4\%) were females and $121(78.6 \%)$ were males from different regions and classifications ( $\bar{X}$ age $=26.87 \pm 1.966$ ). The personal information form and the Referee Self-Efficacy Scale (REFS) were used as data collection tools. In the analysis of the data, descriptive statistics were used to identify self-efficacy levels and to identify demographic variables. In order to compare self-efficacy levels in respect to arithmetic means gender and age self efficacy scores, independent t-test was used and one-way analysis of variance (ANOVA) was used to compare self-efficacy levels of education level and occupations. The Tukey's multiple comparison test was used to determine differences between groups. The results revealed that the referees' self-efficacy levels were high and there were significant differences in self-efficacy levels in terms of gender and educational status. Thus, it is recommended that higher education level be prioritized during the referee selection and promotion and that experience and physical competence be increased to elevate the self-efficacy levels of female referees.
\end{abstract}

Keywords: Self-efficacy, referee, football.

\footnotetext{
* Orcid ID: https://orcid.org/0000-0003-2771-2000, Assist. Prof. Dr., Aydın Adnan Menderes Üniversitesi, Spor Bilimleri Fakültesi Beden Eğitimi ve Spor Eğitimi Bölümü, cdereceli@adu.edu.tr

** Orcid ID: https://orcid.org/0000-0002-3079-4417, Assoc. Prof. Dr.., Aksaray Üniversitesi, Spor Bilimleri Fakültesi Beden Eğitimi ve Spor Eğitimi, unlu68@gmail.com

${ }^{* * *}$ Orcid ID: https://orcid.org/0000-0003-0515-9099, Assoc. Prof. Dr., Aksaray Üniversitesi, Spor Bilimleri Fakültesi Beden Eğitimi ve Spor Eğitimi, kayihan.besyo@gmail.com
} 


\section{INTRODUCTION}

Sports is a combination of physical, mental, and spiritual activities that are carried out in certain rules and has a competitive, socializing, and integrative nature which ultimately aims to satisfy the subconscious desires of humanity such as defeat and power (Özmaden et al., 2016). In contemporary world where sports are fully integrated with economics and politics, refereeing has a very different position and regarded as a profession or task group that is difficult to understand without in-depth examination, although many factors with high level of influence are confined in the profession (Karaçam \& Pulur, 2016). It was determined that the the referees expose to extreme pressure before, during and after the competition from many external factors such as spectators, players, security, press, and referee appointments. Moreover, the referees have an obligation to evaluate the actions taken during the match under the negative conditions and pressure, to make quick decisions, to manage the game, to pay attention to multiple aspects of the game, to maintain order, and to resolve disputes according to their level of experience and knowledge which are denoted as internal factors (Tuero, Tabernero, Marquez and Guillen, 2002). The self-efficacy concept is regarded as one of the important factors for meeting the high performance expectations while fulfilling these obligations. As stated for the first time in the Social Learning Theory of Bandura (1977), the self-efficacy concept provided an effective motivation and power for the formation of behaviors (Bandura, 1977). The self-efficacy concept is defined as the belief that the individual can successfully perform the necessary behaviors that can produce the desired results in a certain area and the ability to perform different levels of performance successfully (Çattık and Aksoy, 2018; Yıldırım, 2015). In other words, selfefficacy is not a function of a person's skills, but defined as a result of their judgment about what they can do by using their skills (Kahyaoğlu \& Yangın, 2007).

The literature search reveled a limited number of studies for referee self-efficacy with some studies on self-efficacy of athletes and coaches (Feltz \& Magyar, 2006; Pineau \& Glass, 2014). The concept of self-efficacy is regarded to have a very important role for athletes, trainers, and managers, and that the same situation applies to the referees (Feltz and Lirgg, 2001; Gill, 2004). The self-efficacy of referees is defined as the perception that the referee has the capacity to carry out tasks related to the job functions (Guillen and Feltz, 2011). The previous research revealed that the self-efficacy level is higher in referees who have more respect for their decisions, are more effective in their performances, more connected to the profession, and highly respected among coaches, managers and other authorities, and have a lower level of stress (Guillen and Feltz, 2011; Tuero et al., 2002).

In the study targeting the relationship between the self-efficacy and tennis performance, Barling and Abel (1983) reported a significant correlation between the self-efficacy and tennis performances and the more skillful and high performing athletes stated that they have higher competence belief (Barling and Abel, 1983). 
Miller and Mc Auley (1987) investigated the free-throw performance and self-efficacy beliefs of basketball players and subjects were randomly divided into target-oriented and non-target-oriented groups in the study. The performances were evaluated every five weeks and the target-oriented group showed higher self-efficacy compared to the non-target oriented group. In addition, the relationship between self-efficacy and performance was higher in the target-oriented group (Miller and Mc Auley, 1987).

George (1994) observed the relationship between self-efficacy and performance in baseball players and investigated whether there were differences in self-efficacy between cognitive and somatic state anxiety levels over a period of nine matches. He concluded that self-efficacy affects the pitching performance of in five games and the anxiety and self-efficacy effected performance in 6 match where the low level of anxiety was related to high self-efficacy (George, 1994).

Mins, Munroe, and Hall (2000) stated that athletes with lower level of self-efficacy needed more motivation than self-efficacious athletes in their study with 50 athletes of wrestling, athletics, and rowing (Mins, Munroe and Hall, 2000).

Öztürk and Şahin (2007) compared self-efficacy of individuals in the 9-13 age group who did and did not do sports. They concluded that there were significant differences between self-efficacy levels between the athletes in the team sports and non-athletes in the study and they also stated that girls who are in team sports on average had higher self-efficacy than boys (Öztürk and Şahin, 2007).

When the research conducted in the field of self-efficacy of the referees were examined, it was observed that the self-efficacy theory and the sources of confidence survey in the sport were initially used (Karaçam and Pulur, 2017; Short, Sullivan and Feltz, 2005). In the preliminary conceptual model, the proposed factors of referee self-efficacy have been determined to include (a) game knowledge and strategic skills, (b) decisionmaking skills, (c) psychological skills, (d) game communication/supervision, and (e) physical fitness (Guillen and Feltz, 2011). Based on these factors, Myers, Feltz, Guillen, and Dithurbide (2012) developed the Referee Self-Efficacy Scale. In addition to the previous model, Myers et al. (2012) incorporated the physical competency factor and developed a more comprehensive scale (Myers et al., 2012).

Karaçam and Pulur (2017) conducted a study on 210 referees working in different branches, and determined that the scale developed by Myers et al. was adapted to Turkish. As a result of the study, it was also stated that the Turkish form of the scale is a valid and reliable measurement instrument along with the physical competency factor (Karaçam and Pulur, 2017).

When all of these studies were examined, it was observed that self-efficacy studies for the athletes and coaches were adequately present in the literature and that the refereeing phenomenon, which is one of the most important parts of the sport, was not 
investigated sufficiently and its relation with the self-efficacy concept was not adequately demonstrated. Therefore, the aim of this study was to determine the selfefficacy levels of soccer referees and to examine their self-efficacy levels in relation to major demographic variables (gender, educational status, and the age of starting the profession).

\section{METHOD}

\section{Research Model}

This research is a descriptive study aimed to determine the relationship between selfefficacy levels of football referees and some demographic variables (gender, educational status, occupation, and age of initiation). Descriptive research is a research model used to elucidate a given situation, to make evaluations in accordance with standards, and to reveal possible relationships between events (Karasar, 2007).

\section{Research Group}

The research group consisted of a total of 154 football referees and referee candidates of whom 33 were (21.4\%) females and 121 (78.6\%) were male from different regions and categories in the $2017-2018$ football season $\left(\bar{X}_{\text {age }}=26.87 \pm 1.966\right)$.

Table 1.

Frequency and percentage distributions of the research group

\begin{tabular}{llll}
\hline Variables & & $\mathrm{f}$ & $\%$ \\
\hline Gender & Female & 33 & 21.4 \\
& Male & 121 & 78.6 \\
\hline Education Level & High School & 34 & 22.1 \\
& Undergraduate & 87 & 56.5 \\
& Graduate & 33 & 21.4 \\
\hline Occupation & Teacher & 34 & 22.1 \\
& Student & 81 & 52.6 \\
& Other & 39 & 25.3 \\
\hline Age of Starting & $16-20$ & 89 & 57.8 \\
Refereeing & 21 and above & 65 & 42.2 \\
\hline
\end{tabular}




\section{Data Collection Tools}

Personal Information Form: The data regarding the gender, education status, occupation, and age of starting refereeing were recorded from the referees in the current study using this form.

Referee Self-Efficacy Scale: In this study, Turkish adaptation (Karaçam and Pulur 2017) of the the original Self-Efficacy Scale (REFS) form developed by Myers, Feltz, Guillen and Dithurbide (2012) was used. The physical competency factor was the first factor of the scale and consisted of five items (1-2-3-4-5), the second factor was pressure and consisted of the three items (12-13-14), the third factor was the decision-making and consisted of three items (9-10-11), the fourth factor was communication and consisted of four items (15-16-17-18), and the fifth factor, the game information, consisted of three items (6-7-8). The scale has a total of 13 items in five-point Likert-type. The grading options for scale items are expressed as "Completely Disagree $=1$ " to "Fully agree $=5$ ". It was stated that there were no items with an inverse score on the scale and that the high scores obtained from each factor of the scale contributed to the high self-efficacy score. The Cronbach alpha internal consistency coefficients for the five-factor structure were calculated as 0.87 for the physical competency factor, 0.87 for the pressure factor, 0.85 for the decision-making factor, 0.80 for the communication factor, and 0.71 for the game information factor. The internal consistency coefficient calculated for the entire scale is 0.90 .

The recalculated Cronbach alpfa internal consistency coefficient was calculated as 0.92 for the physical competency factor, 0.83 for the game information factor, 0.85 for the decision-making factor, 0.88 for the pressure handling factor and 0.89 for the communication factor. Cronbach alpfa internal consistency coefficient for the entire scale was 0.87 .

\section{Data Analysis}

Descriptive statistics were used to determine the self-efficacy level of soccer referees and to gather the demographic variables in this study. Furthermore, in order to compare the mean self-efficacy levels of the gender and age groups, t-test was employed whereas one-way ANOVA was used to compare mean self-efficacy levels of education status and the current occupation variables. Tukey's multiple comparison test was used to determine the difference between the groups. 


\section{FINDINGS}

\section{Self-Efficacy Levels of Referees}

Table 2.

Descriptive statistics of self-efficacy levels of referees $(n=154)$

\begin{tabular}{llll}
\hline Variables & $\bar{X}$ & Ss & $\alpha$ \\
\hline Physical Competency Factor & 22.311 & 3.279 & 0.92 \\
Game Information & 13.675 & 1.714 & 0.83 \\
Communication & 18.428 & 2.263 & 0.89 \\
Decision Making & 13.733 & 1.633 & 0.85 \\
Pressure Handling & 13.837 & 1.873 & 0.88 \\
Total Self-Efficacy Level & 82.013 & 8.421 & 0.87 \\
\hline
\end{tabular}

Table 2 shows that soccer referees' self-efficacy levels are high both in terms of subfactors and overall self-efficacy.

Table 3.

Comparison self-efficacy levels of referees in terms of the gender

\begin{tabular}{|c|c|c|c|c|c|c|c|}
\hline Variables & Gender & $\mathrm{n}$ & $\bar{X}$ & Ss & sd & $\mathrm{t}$ & $\mathrm{p}$ \\
\hline \multirow{2}{*}{$\begin{array}{l}\text { Physical } \\
\text { Competency }\end{array}$} & Female & 33 & 20.878 & 3.903 & \multirow{2}{*}{152} & \multirow{2}{*}{-2.900} & \multirow{2}{*}{$0.004^{*}$} \\
\hline & Male & 121 & 22.702 & 2.987 & & & \\
\hline \multirow[t]{2}{*}{ Game Information } & Female & 33 & 13.121 & 1.866 & \multirow{2}{*}{152} & \multirow{2}{*}{-2.118} & \multirow{2}{*}{0.036} \\
\hline & Male & 121 & 13.826 & 1.646 & & & \\
\hline \multirow[t]{2}{*}{ Communication } & Female & 33 & 17.303 & 3.005 & \multirow{2}{*}{152} & \multirow{2}{*}{-3.327} & \multirow{2}{*}{$0.001^{* *}$} \\
\hline & Male & 121 & 18.735 & 1.918 & & & \\
\hline \multirow[t]{2}{*}{ Decision Making } & Female & 33 & 13.363 & 1.867 & \multirow{2}{*}{152} & \multirow{2}{*}{-1.474} & \multirow{2}{*}{0.142} \\
\hline & Male & 121 & 13.834 & 1.556 & & & \\
\hline \multirow[t]{2}{*}{ Pressure Handling } & Female & 33 & 12.727 & 2.613 & \multirow{2}{*}{152} & \multirow{2}{*}{-4.028} & \multirow{2}{*}{$0.000^{* *}$} \\
\hline & Male & 121 & 14.140 & 1.490 & & & \\
\hline \multirow{2}{*}{$\begin{array}{l}\text { Total } \\
\text { Level }\end{array}$} & Female & 33 & 77.393 & 11.407 & \multirow{2}{*}{152} & \multirow{2}{*}{-3.699} & \multirow{2}{*}{$0.000^{* *}$} \\
\hline & Male & 121 & 83.272 & 6.947 & & & \\
\hline
\end{tabular}


As seen in Table 3, the arithmetic means of physical competence, pressure, and communication factors which are dimensions of referee self-efficacy have a significant gender difference. According to this, male football referees' physical competency, communication competency and pressure handling capacity were found to be higher than the female referees. There was no significant difference between genders in terms of game knowledge and decision-making sub-dimensions.

\section{Comparison of Self-Efficacy Levels According to Starting Age of Refereeing}

Table 4.

Comparison of referee self-efficacy levels in terms of starting age

\begin{tabular}{|c|c|c|c|c|c|c|c|}
\hline Variables & Age & $\mathrm{n}$ & $\bar{X}$ & Ss & $\mathrm{sd}$ & $\mathrm{t}$ & $\mathrm{p}$ \\
\hline \multirow{2}{*}{$\begin{array}{l}\text { Physical } \\
\text { Competency }\end{array}$} & $16-20$ & 89 & 22.415 & 3.168 & & & \\
\hline & $\begin{array}{l}21 \text { and } \\
\text { above }\end{array}$ & 65 & 22.169 & 3.444 & 152 & 0.460 & 0.646 \\
\hline \multirow{2}{*}{$\begin{array}{l}\text { Game } \\
\text { Information }\end{array}$} & $16-20$ & 89 & 13.561 & 1.821 & 152 & \multirow[b]{2}{*}{-0.961} & \multirow[b]{2}{*}{0.338} \\
\hline & $\begin{array}{l}21 \text { and } \\
\text { above }\end{array}$ & 65 & 13.830 & 1.556 & & & \\
\hline \multirow[t]{2}{*}{ Communication } & $16-20$ & 89 & 18.224 & 2.319 & 152 & \multirow[b]{2}{*}{-1.311} & \multirow[b]{2}{*}{0.192} \\
\hline & $\begin{array}{l}21 \text { and } \\
\text { above }\end{array}$ & 65 & 18.707 & 2.170 & & & \\
\hline \multirow[t]{2}{*}{ Decision Making } & $16-20$ & 89 & 13.584 & 1.629 & 152 & \multirow[b]{2}{*}{-1.333} & \multirow[b]{2}{*}{0.185} \\
\hline & $\begin{array}{l}21 \text { and } \\
\text { above }\end{array}$ & 65 & 13.938 & 1.628 & & & \\
\hline \multirow{2}{*}{$\begin{array}{l}\text { Pressure } \\
\text { Handling }\end{array}$} & $16-20$ & 89 & 13.719 & 2.077 & 152 & \multirow[b]{2}{*}{-0.919} & \multirow[b]{2}{*}{0.360} \\
\hline & $\begin{array}{l}21 \text { and } \\
\text { above }\end{array}$ & 65 & 14.00 & 1.551 & & & \\
\hline \multirow{2}{*}{$\begin{array}{l}\text { Total Self- } \\
\text { Efficacy Level }\end{array}$} & $16-20$ & 89 & 81.550 & 8.876 & 152 & \multirow[b]{2}{*}{-0.796} & \multirow[b]{2}{*}{0.427} \\
\hline & $\begin{array}{l}21 \text { and } \\
\text { above }\end{array}$ & 65 & 82.646 & 7.779 & & & \\
\hline
\end{tabular}

When referee self-efficacy levels were compared according to the age of referees, no significant difference was found (Table 4). 


\section{Comparison of Referee Self-Efficacy Levels According to Education Level Variable}

Table 5.

Comparison of referee self-efficacy levels in terms of education level

\begin{tabular}{|c|c|c|c|c|c|c|c|c|}
\hline Variables & Education Level & $\mathrm{n}$ & $\bar{X}$ & Ss & $\mathrm{Sd}$ & $\mathrm{F}$ & $\mathrm{p}$ & $\begin{array}{l}\text { Fark } \\
\text { Tukey } \\
\text { HSD }\end{array}$ \\
\hline \multirow{3}{*}{$\begin{array}{l}\text { Physical } \\
\text { Competency }\end{array}$} & High School & 34 & 20.823 & 3.511 & & & & \multirow[t]{3}{*}{$1<2$} \\
\hline & Undergraduate & 87 & 23.080 & 2.973 & 153 & 6.736 & $0.002^{*}$ & \\
\hline & Graduate & 33 & 21.818 & 3.273 & & & & \\
\hline \multirow{3}{*}{$\begin{array}{l}\text { Game } \\
\text { Information }\end{array}$} & High School & 34 & 13.058 & 2.029 & & & & \multirow[t]{3}{*}{$1<2$} \\
\hline & Undergraduate & 87 & 14.057 & 1.449 & 153 & 5.435 & $0.005^{*}$ & \\
\hline & Graduate & 33 & 13.303 & 1.793 & & & & \\
\hline \multirow{3}{*}{$\begin{array}{l}\text { Communicati } \\
\text { on }\end{array}$} & High School & 34 & 17.764 & 2.686 & \multirow{3}{*}{153} & \multirow{3}{*}{3.692} & \multirow{3}{*}{0.027} & \\
\hline & Undergraduate & 87 & 18.850 & 1.845 & & & & \\
\hline & Graduate & 33 & 18.00 & 2.598 & & & & \\
\hline \multirow{3}{*}{$\begin{array}{l}\text { Decision } \\
\text { Making }\end{array}$} & High School & 34 & 13.294 & 1.850 & \multirow{3}{*}{153} & \multirow{3}{*}{1.823} & \multirow{3}{*}{0.165} & \\
\hline & Undergraduate & 87 & 13.919 & 1.549 & & & & \\
\hline & Graduate & 33 & 13.697 & 1.570 & & & & \\
\hline \multirow{3}{*}{$\begin{array}{l}\text { Pressure } \\
\text { Handling }\end{array}$} & High School & 34 & 13.647 & 1.856 & \multirow{3}{*}{153} & \multirow{3}{*}{1.304} & \multirow{3}{*}{0.274} & \\
\hline & Undergraduate & 87 & 14.046 & 1.758 & & & & \\
\hline & Graduate & 33 & 13.484 & 2.152 & & & & \\
\hline \multirow{3}{*}{$\begin{array}{l}\text { Total Self- } \\
\text { Efficacy Level }\end{array}$} & High School & 34 & 78.705 & 9.615 & \multirow{3}{*}{153} & \multirow{3}{*}{5.977} & \multirow{3}{*}{$0.003^{*}$} & $1<2$ \\
\hline & Undergraduate & 87 & 83.954 & 7.170 & & & & \\
\hline & Graduate & 33 & 80.303 & 8.984 & & & & \\
\hline
\end{tabular}

${ }^{* *} \mathrm{p}<0.01,{ }^{*} \mathrm{p}<0.05$

When Table 5 is analyzed, a significant difference was detected among the education level of football referees in the physical competence and game information dimensions of referee self-efficacy scale. In both dimensions, it was determined that the level of physical competence and game knowledge of the football referees with bachelor's degree was higher than that of high school graduated football referees. In addition, the total score of self-efficacy levels of the football referees with a bachelor's degree were also found to be higher than the high school graduate football referees. 
When we evaluated the competency of communication, decision-making, and pressure handling in respect to the education level, we did not detect any significant difference.

\section{Comparison of Referee Self-Efficacy Levels According to Occupation Variable}

Table 6.

Comparison of referee self-efficacy levels in terms of occupation

\begin{tabular}{|c|c|c|c|c|c|c|c|}
\hline Variables & Occupation & $\mathrm{n}$ & $\bar{X}$ & Ss & Sd & $\mathrm{F}$ & $\mathrm{p}$ \\
\hline \multirow{3}{*}{$\begin{array}{l}\text { Physical } \\
\text { Competency }\end{array}$} & Teacher & 34 & 22.647 & 3.497 & \multirow{3}{*}{153} & \multirow{3}{*}{0.280} & \multirow{3}{*}{0.756} \\
\hline & Student & 81 & 22.148 & 3.417 & & & \\
\hline & Other & 39 & 22.359 & 2.814 & & & \\
\hline \multirow{3}{*}{ Game Information } & Teacher & 34 & 14.235 & 1.232 & \multirow{3}{*}{153} & \multirow{3}{*}{2.688} & \multirow{3}{*}{0.071} \\
\hline & Student & 81 & 13.432 & 1.857 & & & \\
\hline & Other & 39 & 13.692 & 1.688 & & & \\
\hline \multirow{3}{*}{ Communication } & Teacher & 34 & 18.764 & 1.907 & \multirow{3}{*}{153} & \multirow{3}{*}{1.439} & \multirow{3}{*}{0.240} \\
\hline & Student & 81 & 18.135 & 2.448 & & & \\
\hline & Other & 39 & 18.743 & 2.111 & & & \\
\hline \multirow{3}{*}{ Decision Making } & Teacher & 34 & 14.294 & 1.087 & \multirow{3}{*}{153} & \multirow{3}{*}{3.831} & \multirow{3}{*}{0.024} \\
\hline & Student & 81 & 13.419 & 1.787 & & & \\
\hline & Other & 39 & 13.897 & 1.569 & & & \\
\hline \multirow{3}{*}{ Pressure Handling } & Teacher & 34 & 14.352 & 1.276 & \multirow{3}{*}{153} & \multirow{3}{*}{3.969} & \multirow{3}{*}{0.021} \\
\hline & Student & 81 & 13.444 & 2.252 & & & \\
\hline & Other & 39 & 13.837 & 1.151 & & & \\
\hline \multirow{3}{*}{ Self-Efficacy } & Teacher & 34 & 84.294 & 6.157 & \multirow{3}{*}{153} & \multirow{3}{*}{2.609} & \multirow{3}{*}{0.077} \\
\hline & Student & 81 & 80.629 & 9.783 & & & \\
\hline & Other & 39 & 82.897 & 6.451 & & & \\
\hline
\end{tabular}

${ }^{* *} \mathrm{p}<0.01,{ }^{*} \mathrm{p}<0.05$

We compared referee self-efficacy levels of the football referees among different occupations and did not detect significant differences among current occupations (Table 4). 


\section{DISCUSSION, CONCLUSIONS AND SUGGESTIONS}

\section{Discussion}

When the findings of the present research are evaluated in general, the self-efficacy levels of the soccer referees from different categories and regions were found to be high. Furthermore, self-efficacy levels were also found to be high for the physical competence, game knowledge, communication, decision-making, and pressure handling. Some earlier studies reported parallel results with this study. Focusing on the psychological skills rugby referees, Nazarudin et al. (2014) also evaluated the concept of self-efficacy of the referees and they concluded similar results. Diotaiuti, Falese, Mancone, and Purromuto (2017) investigated self-efficacy level of the handball referees reported similar results.

Arithmetic averages of the physical competence, pressure handling, and communication sub-dimensions of referee self-efficacy were significantly different between the two genders. The physical, communicational and pressure handling competencies of the male football referees were found to be higher than those of the female referees. In previous studies, it has been stated that the perceived stress levels of female football referees were higher and their self-confidence levels were lower than those of male refrees (Baştuğ, Duman, Akçakoyun and Karadeniz, 2016) and these results are in congruent with our results. Nevertheless, these results may have arisen due to the fact that women are physically different from men and that physical difference might have a negative relationship with self-efficacy (Çakmak, 2011). Another potential factor for the present results is that the football has traditionaly been a male dominant sport where females are currently struggling to take part. No significant difference was found between the two genders in terms of game information and decision-making subdimension. A number of studies support these results (Baştuğ, Duman, Akçakoyun and Karadeniz, 2016).

Referees' self-efficacy levels were analyzed based on the starting age of refereeing and no significant difference was found in respect to the starting age. Although some studies indicate that the refree experience positively affects the level of refereeing self-efficacy (Diotaiuti et al., 2017; Nazrudin et al., 2014), no research was found to target the starting age of refreeing. Demirbaș (1992) concluded that there is an increase in the decisionmaking ability and effectiveness of the decisions in pararllel to the aging (Demirbaş, 1992). The fact that the age of the football referees participating in the study was low ( $\bar{X}$ age $=26.87 \pm 1.966$ ) may have caused the insignificant results.

A significant difference was found among football referee groups with different educational levels in terms of physical competence and game information dimensions. In both dimensions, it was determined that the level of physical competence and game knowledge of the football referees with an undergraduate degree was higher than those with a high school degree. In addition, the total self-efficacy score of the football referees with an undergraduate degree were found to be higher than the football referees with 
high school degree. Some earlier studies reported similar results. People with higher education level were reported to use more logical decision-making strategy than those with medium and low education level when making critical decisions (Yiğit 2005). Similarly, people with lower levels of education indicated a hastier decision-making behavior (Ersever, 1996). In a different study, the authors concluded that as the level of education decreased, the referees behaved in a timid manner and tended to hasitate from taking responsibility (Uzunoğlu, 2008).

There was no significant difference among the groups with different education levels in terms of the competency of communication, decision-making or pressure handling. These results conficted with some earlier studies (Özdayı and Uğurlu, 2015).

Referees' self-efficacy levels were compared in terms of the type of job occupancy and no significant difference was found. Some of the previous research concluded contradicting conclusions (Uzunoglu, 2008; Sahin and Fisekcioglu, 2009; Bastug et al., 2016). The absence of a wide variety of the occupations among the referees participated to the present research may have produced this result.

\section{Conclusion}

In conclusion, the self-efficacy levels of the football referees participating in the study were high and gender and education level were important predictors of self-efficacy levels. In the Simmons (2009) report on the football referees prepared for FIFA (Fédération Internationale de Football Association), the players' perceptions of justice and accuracy in the decisions were affected by the referees' procedural correctness. The players also expressed a need for fair treatment indicators. In the emotionally charged uncertainty of competitive football, the referees are expected to deliberately communicate their ability and intent to provide a fair, safe, and foreseeable game environment. In this respect, it has been emphasized in the report that besides the ability and physical competence in the criteria of being a referee, the education level be taken into account to the as much as possible (Simmons, 2009). Research findings reported here also demosntrated that the education level is an important variable. Consequently, keeping the education levels as high as possible in the referee selection criteria and taking education level into consideration during the promotion of refrees to higher leagues is thought to increase the quality of football and sports.

\section{Suggestions}

According to the research results, gender was found to be a significant predictor of selfefficacy level of referees where female soccer referees had a lower self-efficacy score. One of the reasons for the situation oserved here is that the football culture among women is not well established and females do not have sufficient football experience. As stated previously, the knowledge develops with successful experiences and then this 
experience turns into expertise (Güçlü and Sotirofski, 2006). Therefore, female referees are expected to gain more refereeing experience in order to increase their self-efficacy levels. In addition, physical competence is also one of the important factors affecting self-efficacy (Myers et al., 2012). Thus, it is thought that the increase in the physical competence the female referees will ultimately contribute to their self-efficacy levels.

\section{References}

Bandura, A. (1977). Self-Efficacy Theory: Toward a Unifying Theory of Behavioral Change. Psychological Review, 84, 191-225.

Barling, J. \& Abel, M. (1983). Self-efficacy beliefs and tenis performance. Cognitive Therapy and Research, 7, 265-272.

Baştuğ, G., Duman, S., Akçakoyun, F., \& Karadeniz, F. (2016). Futbol hakemlerinde; stres, özgüven, karar verme. Journal of Human Sciences, 13(3), 5399-5406.

Çakmak, T. M. (2011). Faal futbol hakemlerinin stres kaynaklarının tespiti (Yüksek Lisans Tezi, Gazi Üniversitesi, Sağlık Bilimleri Enstitüsü, Ankara). https://tez.yok.gov.tr/UlusalTezMerkezi adresinden edinilmiştir.

Çattık, M., \& Aksoy, V. (2018). Gelişimsel Yetersizliği Olan Çocukların Ebeveynlerinin Sosyal Destek, Öz-Yeterlik ve Yaşam Doyum Düzeyleri Arasındaki İlişkinin İncelenmesi. Eğitim Ve Bilim, 1-13.

Demirbaş, H. (1992). Suçlu ve Suçlu Olmayan Ergenlerin Karar Verme Davranışlarının Karşılaştırılması (Yükseklisans Tezi, Ankara Üniversitesi Sosyal Bilimler Enstitüsü, Ankara).

Diotaiuti, P., Falese, L., Mancone, S., \& Purromuto, F. (2017). A structural Model of Self-efficacy in Handball Referees. Frontiers in psychology, 8, 811.

Ersever, Ö. H. (1996). Karar Verme Stratejileri Kazandırma Programın ve Etkileşim Grubu Deneyiminin Üniversite Öğrencilerinin Karar Verme Stilleri Üzerine Etkileri (Doktora Tezi, Ankara Üniversitesi Sosyal Bilimler Enstitüsü, Ankara).

Feltz D.L., \& Lirgg, C. (2001). Self-efficacy Beliefs of Athletes, Teams, and Coaches. In: Singer R, Hausenblas, Janelle C. (Eds). Handbook of Sport Psychology (pp. 340-361) New Jersey, USA: John Willey and Sons.

Feltz, D. L., \& Magyar, T. M. (2006). Self-efficacy and adolescents in sport and physical activity. Adolescence and education, 4, 161-179.

Gill, D. L. (2000). Psychological Dynamics of Sport an Exercise. Illinois, USA: Human Kinetics.

George, T. R. (1994). Self-confidence and baseball performance: A casual examination of self efficacy theory. Journal of Sport and Exercise Psychology, 16, 381-399

Guillén, F., \& Feltz, D. L. (2011). A conceptual model of referee efficacy. Frontiers in psychology, 2, 25.

Güçlü, N., \& Sotirofski, K. (2006). Bilgi yönetimi. Türk Eğitim Bilimleri Dergisi, 4(4), 351-373. 
Kahyaoğlu, M., \& Yangın, S. (2007). İlköğretim öğretmen adaylarının, mesleki öz-yeterliklerine ilişkin görüşleri. Kastamonu Eğitim Dergisi, 15(1), 73-84.

Karaçam, A., \& Pulur, A. (2016). Identification the Relation between Active Basketball Classification Referees' Empathetic Tendencies and Their Problem-Solving Abilities. Universal Journal of Educational Research, 4, 1912 - 1917.

Karaçam, A., \& Pulur, A. (2017). Hakemler İçin Mesleki Haz Ölçeği: Geçerlik ve Güvenirlik Çalışması-HIMHÖ. Gaziantep Üniversitesi Spor Bilimleri Dergisi, 3(2), 35-45.

Karasar, N. (2007). Bilimsel Araştırma Yöntemi. Ankara: Nobel Yayın Dağıtım Ltd. Şti.

Mills, K. D., Munroe, K. J., \& Hall, C. R. (2000). The relationship between imagery and self-efficacy in competitive athletes. Imagination, Cognition and Personality, 20(1), 33-39.

Miller, J. T., \& McAuley, E., (1987). Effects of goal setting training program on basketball freethrow self efficacy and performance. The Sport Psychologist, 1, 103-113

Moritz, S.E., Feltz, D.L., Fahrbach, K.R., \& Mack, D.E. (2000). The relation of self-efficacy measures to sport performance: a meta-analytic review. Research Quarterly for Exercise and Sport, 71, 280-294.

Myers, N. D., Feltz, D. L., Guillén, F., \& Dithurbide, L. (2012). Development of, and initial validity evidence for, the Referee Self-Efficacy Scale: A multistudy report. Journal of sport and Exercise Psychology, 34(6), 737-765.

Nazarudin, M. N., Noordin, H., Suppiah, P. K., Abdullah, M. R., Fauzee, M. S. O., \& Abdullah, N. M. (2014). Psychological skills assessment and referee rugby sevens performance. Jurnal Pemikir Pendidikan, 5, 165-184.

Özdayı, N., \& Uğurlu, M. F. (2015). Futbol Hakemlerinin Duygusal Zekâ ve İletişim Beceri Düzeyleri Arasındaki İliş̧kinin İncelenmesi, Uluslararası Spor. Egzersiz ve Antrenman Bilimi Dergisi, 1(1), 31-39.

Özmaden, M., Yıldız, Y., Ekici, S., \& Dohman, Z. (2016). Sporun Üniversite Öğrencilerinde Mutluluk Düzeyine Etkisinin Çeșitli Değişkenlere Göre Incelenmesi. ERPA International Congresses on Education, Sarajevo/Herzegovina, 328-333.

Öztürk, F., \& Şahin, Ş. K. (2007). Spor yapan ve yapmayan 9-13 grubu bireylerin sosyal yetkinlik beklentisi puanlarının karşılaştırılması. Illköğretim Online, 6(3), 469-479.

Pineau, T. R., Glass, C. R., Kaufman, K. A., \& Bernal, D. R. (2014). Self-and team-efficacy beliefs of rowers and their relation to mindfulness and flow. Journal of Clinical Sport Psychology, 8(2), 142-158.

Simmons, P. (2009). Justice, culture and football referee communication. Final report of Joao Havelange Research Scholarship study to FIFA/CEIS Scientific Committee, Switzerland.

Short, S. E., Sullivan, P. S., \& Feltz, D. L. (2005). Development and preliminary validation of the collective efficacy questionnaire for sports. Measurement in Physical Education and Exercise Science, 9, 181-202.

Tuero, C., Tabernero, B., Marquez, S., \& Guillen, F. (2002). Análisis de los factores que influyen en la práctica del arbitraje [Analysis of the factors affecting the practice of refereeing]. SCAPE, 1(1), 7-16.

Uzunoğlu, Ö. U. (2008). Türk Futbol Hakemlerinin Karar Verme Stillerinin Klasmanlarına Ve Bazı Değişkenlere Göre İncelenmesi (Yüksek Lisans Tezi, Selçuk Üniversitesi, Sağlık Bilimleri 
Enstitüsü, Beden Eğitimi ve Spor A.B.D., Konya). https://tez.yok.gov.tr/UlusalTezMerkezi adresinden edinilmiştir.

Yıldırım, İ. (2015). Revised version of physical education teachers' self-efficacy scale. Journal of Human Sciences, 12(1), 870-886.

Yiğit, A. (2005). Lise Öğrencilerinin Karar Verme Davranışlarının Bazı Değiş̧kenlere Göre Yordanması (Yüksek Lisans Tezi, Ege Üniversitesi Sosyal Bilimler Enstitüsü Rehberlik ve Psikolojik Danışmanlık Bilim Dalı, İzmir). https://tez.yok.gov.tr/UlusalTezMerkezi adresinden edinilmiştir. 